\title{
Digestible amino acids and enzymes in broiler diets: effects on carcass composition of two broiler strains
}

\author{
W. Szczurek \\ National Research Institute of Animal Production, \\ Department of Animal Nutrition and Feed Science \\ 32-083 Balice, Poland
}

\begin{abstract}
A factorial design experiment was conducted to test the effects of two methods of feed formulation, i.e. based on total (TAA) vs digestible (DAA) amino acids and a multi-enzyme preparation in diets with different sources of plant protein, and two energy levels on carcass parameters, especially breast (BM) and breast + leg muscles (VM) content, of two broiler strains (ISA 215 and Ross 308). Treatment diets were fed from 22 to 42 days of age. Overall, Ross birds deposited relatively more BM and VM muscles than ISA broilers. The diet with a lower energy level decreased BM yield in the faster-growing ISA strain. Formulating diets on the basis of DAA vs TAA yielded higher BM and VM percentages in both strains. Enzyme supplementation had a positive effect on BM (Ross) and VM (ISA) yields. In both genotypes feed formulation based on DAAs appeared more effective in improving carcass meatiness than enzyme supplementation.
\end{abstract}

KEY WORDS: digestible amino acids, feed enzymes, protein sources, meat yield, broiler strain

\section{INTRODUCTION}

The EU suspension on feeding most animal meals to poultry necessitates undertaking studies on nutritional strategies for optimizing the carcass quality of broilers fed plant proteins only. Genetic strain has a major impact on meat deposition in broilers. The use of feed enzymes improves the nutritive value of poultry diets based on cereals and should enhance utilization of such protein sources as legume seeds and rapeseed products. Recent studies with broilers have shown that digestible amino acids (DAA) are superior to the use of total amino acids (TAA) in formulating diets containing protein sources that are less well digested than soyabean meal (Bryden et al., 2004). The main objective of this work was to evaluate meat yields in

\footnotetext{
${ }^{1}$ Corresponding author: e-mail: witen@poczta.onet.pl
} 
two broiler strains as influenced by feed formulation with DAA vs TAA and enzyme supplement in diets differing in energy level and protein source.

\section{MATERIAL AND METHODS}

The experiment was conducted on two commercial strains of broilers (ISA 215 and Ross 308). From day one of age the birds were maintained on the same starter type diet. On day 22 the chickens ( 400 birds per strain) were randomized across 40 cages $(5 \hat{\jmath}+5$ per cage). From days 22 to 42 both genotypes received two treatment diets with different formula structure and energy content (D1-12.95; D2-12.23 $\mathrm{MJ} \mathrm{AME}_{\mathrm{N}} / \mathrm{kg}$ ), formulated either on a TAA or DAA basis (Table 1) and fed with or without $1 \mathrm{~g} / \mathrm{kg}$ of an enzyme preparation ( $\beta$-glucanase, xylanase, cellulase, protease, amylase). The levels of total Lys 9.6, Met 4.3, Met + Cys 7.8, Trp 1.8 and Thr 6.6 $\mathrm{g} / \mathrm{kg}$ or these values converted into DAAs $(8.2,4.0,6.8,1.6$ and $5.7 \mathrm{~g} / \mathrm{kg}$, respectively) using the methodology of Dalibard and Paillard (1995) were applied in the feed formulations. Dietary contents of Lys, Met + Cys and Thr were adjusted using feed-grade crystalline amino acids (AA). On day 43 ten birds (both sexes) from each treatment group were fasted $12 \mathrm{~h}$, weighed and slaughtered. The cool eviscerated carcasses were weighed and dissected to obtain breast and leg muscles, and abdominal fat pads. The carcass yield (CY) was calculated on the basis of live body weight. Data for both strains were analysed separately by three-way analysis of variance. Overall and main effect means were compared using Duncan's range test. Linear contrasts for some pre-planned comparisons were tested for significance.

Table 1. Main ingredients and crude protein content of experimental diets (D1 and D2) formulated on a total ${ }^{1}$ (TAA) or digestible ${ }^{1}$ (DAA) amino acid basis, $\mathrm{g} / \mathrm{kg}$

\begin{tabular}{lcccc}
\hline Item & D1/TAA & D1/DAA & D2/TAA & D2/DAA \\
\hline Barley & 210 & 210 & 321 & 316 \\
Maize & 284 & 286 & 130 & 130 \\
Pea seeds (P. sativum) & 100 & 100 & 150 & 150 \\
Lupin seeds (L. angustifolius) & 70 & 60 & 60 & 60 \\
Faba beans (Vicia faba) & & & 60 & 50 \\
Rape seeds (full fat) & 150 & 150 & & \\
Soyabean meal & 80 & 90 & 5 & 20 \\
Rapeseed meal & & & 150 & 150 \\
Crude protein & 161 & 161 & 165 & 168 \\
\hline
\end{tabular}

1 TAA values are analysed (HPLC), DAA values are calculated on the basis of analysed amino acid composition of raw feedstuffs using published true faecal AA digestibility coefficients

\section{RESULTS AND DISCUSSION}

The performance results obtained in this experiment were described in a previous paper (Szczurek, 2004) and showed that from days 22 to 42 of life Ross 
chickens required a higher concentration of dietary protein than ISA birds. Smith and Pesti (1998) found that the maximum body weight response for 39-day-old Ross males was at the $24 \%$ protein level. Nevertheless, as expected, Ross birds deposed relatively more breast (BM) and valuable (breast + leg) muscles (VM) in their carcasses than ISA broilers (Table 2). As opposed to Ross, faster-growing ISA birds were more sensitive to feed energy value and composition. The lowerenergy diet D2 with faba beans and rapeseed meal significantly decreased CY and $\mathrm{BM}$ yield in this strain.

Table 2. Post-slaughter parameters of ISA 215 and Ross 308 chickens (sexes combined) as influenced by feed formula and energy level (Diet), formulation method (AA) and enzyme supplementation (Enzymes)

\begin{tabular}{|c|c|c|c|c|c|c|c|c|c|c|}
\hline \multirow{2}{*}{$\begin{array}{l}\text { Parameter } \\
\text { and strain }\end{array}$} & \multicolumn{2}{|c|}{$\begin{array}{l}\text { Live body } \\
\text { weight, } g\end{array}$} & \multicolumn{2}{|c|}{$\begin{array}{l}\text { Carcass } \\
\text { yield, } \%\end{array}$} & \multicolumn{2}{|c|}{$\begin{array}{l}\text { Breast meat } \\
\text { yield }^{3}\end{array}$} & \multicolumn{2}{|c|}{$\begin{array}{l}\text { Valuable meat } \\
\text { yield }^{3} \\
\end{array}$} & \multicolumn{2}{|c|}{$\begin{array}{l}\text { Abdominal } \\
\text { fat }^{3}\end{array}$} \\
\hline & ISA & Ross & ISA & Ross & ISA & Ross & ISA & Ross & ISA & Ross \\
\hline Overall mean & $2239^{\mathrm{A}}$ & $1973^{\mathrm{B}}$ & 74.7 & 74.8 & $20.8^{\mathrm{A}}$ & $21.6^{\mathrm{B}}$ & $41.6^{\mathrm{a}}$ & $42.0^{\mathrm{b}}$ & $2.50^{\mathrm{a}}$ & $2.24^{\mathrm{b}}$ \\
\hline \multicolumn{11}{|c|}{$\begin{array}{l}\text { Main effect means for carcass traits } \\
\text { Diet }^{1}\end{array}$} \\
\hline D1 & & & $75.1^{\mathrm{a}}$ & 75.0 & $21.1^{\mathrm{A}}$ & 21.7 & 41.7 & 42.2 & 2.59 & 2.31 \\
\hline D2 & & & $74.4^{b}$ & 74.6 & $20.5^{\mathrm{B}}$ & 21.4 & 41.5 & 41.9 & 2.41 & 2.17 \\
\hline \multicolumn{11}{|l|}{$\mathrm{AA}^{1}$} \\
\hline TAA & & & $74.1^{\mathrm{A}}$ & 74.7 & $20.3^{\mathrm{A}}$ & $21.0^{\mathrm{A}}$ & $40.8^{\mathrm{A}}$ & $41.2^{\mathrm{A}}$ & 2.54 & $2.43^{\mathrm{a}}$ \\
\hline DAA & & & $75.4^{\mathrm{B}}$ & 75.0 & $21.3^{\mathrm{B}}$ & $22.1^{\mathrm{B}}$ & $42.4^{\mathrm{B}}$ & $42.9^{\mathrm{B}}$ & 2.46 & $2.05^{\mathrm{b}}$ \\
\hline \multicolumn{11}{|l|}{ Enzymes $^{2}$} \\
\hline $\mathrm{NE}$ & & & $74.4^{\mathrm{a}}$ & 74.6 & 20.6 & $21.2^{\mathrm{a}}$ & $41.2^{\mathrm{a}}$ & 41.6 & 2.55 & 2.26 \\
\hline $\mathrm{E}$ & & & $75.1^{\mathrm{b}}$ & 75.1 & 21.0 & $22.0^{\mathrm{b}}$ & $42.0^{\mathrm{b}}$ & 42.4 & 2.45 & 2.22 \\
\hline Pooled SEM & & & 0.17 & 0.16 & 0.13 & 0.15 & 0.21 & 0.24 & 0.08 & 0.10 \\
\hline \multicolumn{11}{|c|}{ Linear contrasts for treatment combinations } \\
\hline D1/TAA vs I & /DAA & & $* *$ & NS & $*$ & $*$ & * & * & NS & NS \\
\hline D2/TAA vs I & 2/DAA & & $* *$ & NS & $* *$ & $* *$ & $* *$ & $* *$ & NS & $*$ \\
\hline D1/NE vs D & & & $(*)$ & NS & NS & $(*)$ & NS & $(*)$ & NS & NS \\
\hline $\mathrm{D} 2 / \mathrm{NE}$ vs D2 & & & $(*)$ & $(*)$ & $(*)$ & $*$ & $(*)$ & $(*)$ & NS & NS \\
\hline
\end{tabular}

${ }^{1}$ for explanations see Table $1 ;{ }^{2} \mathrm{NE}$ - no enzymes, E - with enzymes; ${ }^{3} \%$ of cold carcass weight overall (ISA vs. Ross) and main effect means (columns) with different letters differ significantly: a, b $-\mathrm{P}<0.05$; $\mathrm{A}, \mathrm{B}-\mathrm{P}<0.01$; contrasts: $\mathrm{ns}-\mathrm{P}>0.05 ;(*)-0.05<\mathrm{P}<0.20$; * $\mathrm{P} \leq 0.05$; ** $-\mathrm{P} \leq 0.01$

It is believed that DAA reflect the amount of AA available for production purposes more closely than TAA. In this study, formulation of diets with DAA yielded higher BM and VM percentages for both strains. Recently, the advantages of DAAbased diets in terms of meat and fat content in Cobb broilers were demonstrated by Bryden et al. (2004). It seems that the benefits from enzymes, i.e. higher BM (Ross) and VM (ISA) yields, were due to diminishing the effects of viscous $\beta$-glucans from barley (Bedford and Schultze, 1998). Under conditions of reduced digesta viscosity, dietary proteins might become readily available for hydrolysis and this could 
result in a greater supply of AAs for muscle formation. With regard to all evaluated carcass parameters, no synergic effects between experimental factors were observed (no significant interactions within each genotype occurred). However, from the practical point of view it is important that in both genotypes enzyme supplementation appeared less effective in improving carcass meatiness than feed formulation with DAA. For both diets (D1 and D2) TAA vs DAA contrasts were at markedly higher significance levels than the NE vs E contrasts (Table 2).

\section{CONCLUSIONS}

Both formulation of feed with DAA values and application of exogenous enzymes may be useful for enhancing meat yield in commercial broilers fed diets containing barley, legume seeds and rape seed products. More pronounced beneficial effects can be expected from the use of DAA formulation.

\section{REFERENCES}

Bedford M.R., Schultze H., 1998. Exogenous enzymes for pigs and poultry. Nutr. Res. Rev. 11, 91-114

Bryden W.L., Li X., Nigusti Ayu M., Huang K.H., Pym R.A.E., 2004. Growth performance of broilers fed diets formulated using digestible amino acid values. In: Proceedings of $22^{\text {nd }}$ World's Poultry Congress, Istanbul (Turkey), p. 409

Dalibard P., Paillard E., 1995. Use of the digestible amino acid concept in formulating diets for poultry. Anim. Feed Sci. Tech. 53, 189-204

Smith E.R., Pesti G.M., 1998. Influence of broiler strain cross and dietary protein on the performance of broilers. Poultry Sci. 77, 276-281

Szczurek W., 2004. Effects of feed formulation with total versus digestible amino acids and enzyme supplementation on the performance of broilers of different genotypes (in Polish). Rocz. Nauk. Zoot. Suppl. 20, 267-271

\section{STRESZCZENIE}

Strawne aminokwasy i enzymy w paszy dla brojlerów: wpływ na jakość tuszek kurcząt o różnym genotypie

Zbadano możliwość polepszenia jakości tuszek kurcząt brojlerów żywionych mieszankami o zróżnicowanym składzie recepturowym i wartości energetycznej, w następstwie bilansowania białka diet według strawnych aminokwasów (DAA) lub zastosowania dodatku wieloskładnikowego preparatu enzymatycznego. Obydwa zabiegi okazały się skuteczne w zwiększeniu ogólnego umięśnienia tuszek kurcząt ISA 215 i Ross 308 odchowywanych od 22 do 42 dnia życia na mieszankach jęczmienno-kukurydziano-sojowych, z udziałem takich surowców białkowych jak rzepak, śruta rzepakowa i nasiona strączkowych. W porównaniu z efektami uzyskanymi przy stosowaniu enzymów, stwierdzono większy zakres poprawy badanych wskaźników wydajności mięsnej kurcząt danych genotypów przy bilansowaniu białka z uwzględnieniem zawartości DAA. 